\section{University of London}

THE period for which Mr. H. L. Eason was appointed as principal of the University of London terminates on September 30, and the Senate has docided that the post shall not for the present be re-filled. Mr. Eason has held the office of principal since July 1937, having been a member of the Senate from 1911 and vice-chancellor from 1935. The Senate, with the concurrence of the Court, has appointed Mr. Harold Claughton as acting principal as from October 1. Mr. Claughton has been clerk of the Court of the University since the institution of the Court in 1929, and has acted as deputy to the Principal since June 1940. From 1924 until 1929 he was financial officer and secretary to the Senate.

Under an emergency statute made by the Senate, no elections by Convocation of persons to be members of the Senate will be held in the year 1941, and those persons who are due to retire on the second Tuesday in May of this year will continue to be members of the Senate until the second Tuesday in May 1942. Under another emergency statute no elections to the offices of chairman of Convocation and deputy chairman of Convocation are to be conducted before March 1, 1942, and the present holders of these offices will continue in office until the tenth day of May 1942.

Dr. J. H. Gray has been appointed, as from May 1, to the University chair of anatomy tenable at St. Mary's Hospital Medical School. Since 1937 he has been senior demonstrator in anatomy at University College.

The following titles have been conferred in respect of posts held at the College indicated : professor in dental surgery on Dr. E. C. Sprawson (London Hospital Medical College); reader in mathematics on Dr. Theodor Esterman (University College) and on Mr. A. C. Stevenson (University College).

The Worshipful Company of Clothworkers has established a fellowship for graduates in science in the University. The fellowship is to be known as the "William Gilles Fellowship in Science" and will be open to internal or external graduates of the University. The award will be made biennially and will be of the value of about $£ 220$.

The degree of D.Sc. has been conferred on: Mr. P. A. I. Gorer, of Guy's Hospital Medical School; Mr. D. W. W. Henderson, of the Lister Institute of Preventive Medicine; and Mr. R. W. Haines, of St. Thomas's Hospital Medical School.

\section{University of St. Andrews}

THE "University of St. Andrews: Handbook of the United College" published by the St. Andrews University Press is a neat little brochure clad in the scarlet of the well-known gown. The University stands first in Scotland in age, and the latest of its senior foundations, the College of St. Mary, is of 1537. That of 1450 is still represented by the tower of St. Salvator. conspicuous from the sea. The unique graduate rolls date from 1413. Quaint customs survive such as Kate Kennedy Day. There was a period of decay which Johnson saw ; but the College revived to produce its full share of eminent men and a reputation for research in chemistry. The successful rigour of the past is shown by a student who entered in 1819 and lived for more than six months on little more than £14. Games were prohibited in the monastic College of St. Leonard except a weekly visit to the links in the company of a Master. "It takes a heid to play golf," as a famous exponent of it once remarked. Considerable use has been made of the book on "Historic St. Andrews and Its University" by Prof. J. Read, professor of chemistry there, while Mr. John Hinton Read has provided most of the photographs for the effective illustrations.

\section{Announcements}

Prof. J. B. Conant, president of Harvard University, who is visiting Great Britain to discuss scientific collaboration with the United States, has had conferred on him the honorary degree of doctor of science of the University of Oxford.

Prof. Edward A. Doisy, professor of biochemistry in the School of Medicine of St. Louis University, has been awarded the Willard Gibbs Medal for 1941. This medal, one of the highest distinctions in chemical science, is given annually by the Chicago Section of the American Chemical Society. Dr. Doisy accomplished the isolation of vitamin $\mathrm{K}$ from dried alfalfa leaf meal and putrefied sardine meal in 1939. Before that he had, in 1929, isolated theelin, female sex hormone and, in 1936, dihydrotheelin, another sex hormone.

Dr. Dirk Brouwer, associate professor of astronomy at Yale, has been promoted to a full professorship, and has been appointed director of the Yale University Observatory in succession to Dr. Frank Schlesinger, who retires in June next.

THE supply of radium amounting to $6 \mathrm{gm}$. of the Paris Curie Institute, which had been sent into the country before the entrance of the Germans, has now been returned to Paris.

AN Institute for Tropical and Subtropical Diseases has been opened at Modena under the direction of Prof. Giovanno Serra, formerly director of the hospitals at Albertville in the Belgian Congo.

THE National Book Council, 3 Henrietta Street, London, W.C.2, is sending out lists of books specially selected for use in factories and workshops. The first issue consists of two lists in a portfolio; these lists will be supplemented at regular intervals. The titles, publishers and prices of books are mentioned, and a brief note on each entry indicates its scope. The lists are being sent free of charge to some 5,000 engineering firms in Great Britain.

Erratum. The title of the book by Prof. M. G. Mellon reviewed in NatuRE of March 15, p. 310, was incorrectly printed as "Chemical Productions"; the book, which is published by the McGraw-Hill Book Co., Inc., is entitled "Chemical Publications". 